University of Nebraska - Lincoln

DigitalCommons@University of Nebraska - Lincoln

\title{
Effect of distillers grains moisture and inclusion level in livestock diets on greenhouse gas emissions in the corn-ethanol-livestock life cycle
}

\author{
Virgil R. Bremer \\ University of Nebraska - Lincoln, vbremer2@unl.edu \\ Andrea K. Watson \\ University of Nebraska at Lincoln, awatson3@unl.edu \\ Adam J. Liska \\ University of Nebraska-Lincoln,, aliska2@unl.edu \\ Galen Erickson \\ University of Nebraska - Lincoln, gerickson4@unl.edu \\ Kenneth Cassman \\ University of Nebraska - Lincoln, kcassman1@unl.edu \\ See next page for additional authors
}

Follow this and additional works at: https://digitalcommons.unl.edu/bseliska

Part of the Biological Engineering Commons

Bremer, Virgil R.; Watson, Andrea K.; Liska, Adam J.; Erickson, Galen; Cassman, Kenneth; Hanford, Kathryn J.; and Klopfenstein, Terry, "Effect of distillers grains moisture and inclusion level in livestock diets on greenhouse gas emissions in the corn-ethanol-livestock life cycle" (2011). Adam Liska Papers. 11.

https://digitalcommons.unl.edu/bseliska/11

This Article is brought to you for free and open access by the Biological Systems Engineering at DigitalCommons@University of Nebraska - Lincoln. It has been accepted for inclusion in Adam Liska Papers by an authorized administrator of DigitalCommons@University of Nebraska - Lincoln. 


\section{Authors}

Virgil R. Bremer, Andrea K. Watson, Adam J. Liska, Galen Erickson, Kenneth Cassman, Kathryn J. Hanford, and Terry Klopfenstein 


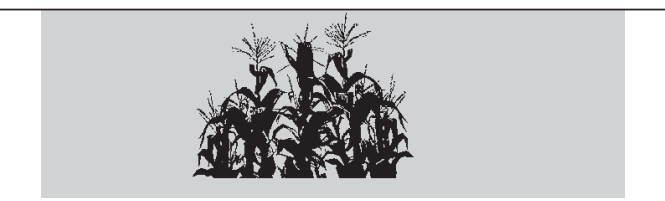

\title{
$E_{\text {ffect of distillers grains moisture }}$ and inclusion level in livestock diets on greenhouse gas emissions in the corn-ethanol- livestock life cycle ${ }^{1}$
}

\begin{abstract}
V. R. Bremer, ${ }^{*}$ A. K. Watson, ${ }^{*}$ A. J. Liska,† G. E. Erickson, ${ }^{\star}$ PAS, K. G. Cassman,‡ K. J. Hanford, $\S^{*}$ and T. J. Klopfenstein ${ }^{* 2}$ *Department of Animal Science, and †Department of Biological Systems Engineering, University of Nebraska, Lincoln 68583; ¥Center for Energy Sciences Research and Department of Agronomy and Horticulture, Lincoln, NE 68583-0724; and §Department of Statistics, University of Nebraska, Lincoln 68583-0963
\end{abstract}

\begin{abstract}
A model was previously developed (Biofuel Energy Systems Simulator; www. bess.unl.edu) to predict greenhouse gas (GHG) emissions and net energy yield when ethanol is produced from corn. The model also predicts feedlot cattle, dairy cattle, and swine performance and feed replacement value of ethanol coproducts. Updated equations that predict performance of feedlot cattle fed 0 to $40 \%$ of dietary DM as corn wet (WDGS), modified (MDGS), or dry (DDGS) distillers grains plus solubles replacing dry-rolled and high-moisture corn were developed and incorporated into the model. Equations were derived from pen-level performance for 20 finishing studies evaluating WDGS, 4 evaluating

\footnotetext{
${ }^{1}$ A contribution of the University of Nebraska-Lincoln Agricultural Research Division, supported in part by funds edu
} provided through the Hatch Act. ${ }^{2}$ Corresponding author: tklopfenstein1@unl.
\end{abstract}

$M D G S$, and 4 evaluating DDGS conducted at the University of Nebraska. Feeding value of WDGS was 145 to 131\% of corn replaced when included at 20 to $40 \%$ of diet DM due to a quadratic $(P<0.01)$ increase in $G: F$. The feeding value of MDGS was 124 to $117 \%$ with a quadratic $(P<0.01)$ increase in $G: F$ and 112 to $110 \%$ for DDGS with a linear $(P<0.01)$ increase in G:F. Midwest corn-ethanol-livestock life cycle $G H G$ reduction relative to gasoline $\left(97.7 \mathrm{~g} \mathrm{CO}_{\text {o }}\right.$ equivalent/MJ of ethanol) was 61 to $57 \%$ when WDGS was fed to feedlot cattle for 20 to $40 \%$ diet inclusion. Feeding MDGS and DDGS to feedlot cattle reduced $G H G$ emissions from the corn-ethanol-cattle system by 53 to $50 \%$ and 46 to $41 \%$, respectively. Feeding WDGS to feedlot cattle was the optimum feed use of distillers grains plus solubles based on feeding performance and GHG reduction.

Key words: cattle performance, distillers grains plus solubles, greenhouse gases, life cycle assessment

\section{INTRODUCTION}

Corn (Zea mays) distillers grains plus solubles (DGS) are an important part of the corn-ethanol-livestock life cycle when comparing greenhouse gas (GHG) emissions of ethanol to gasoline. Distillers grains contain energy, protein, and minerals and can replace corn, urea, and soybean meal in livestock diets. The energy and CP replacement value of DGS is dependent on dietary inclusion level and livestock class (Klopfenstein et al., 2008b). Ethanol-plant energy use and associated GHG emissions are affected by the moisture content of DGS produced. All ethanol plants produce wet DGS (WDGS; 65 to $69 \%$ moisture), but some remove moisture to manufacture modified DGS (MDGS; 52 to $58 \%$ moisture) or dried DGS (DDGS; 8 to $12 \%$ moisture). Ethanol-plant energy use (e.g., mainly natural gas) to remove moisture has been identified as a parameter of importance in comparing GHG emissions from ethanol 
relative to gasoline (Liska et al., 2009; Bremer et al., 2010b).

The Biofuel Energy Systems Simulator (BESS; www.bess.unl.edu) was developed to compare life cycle GHG emissions from ethanol production relative to gasoline as a motor fuel, while accounting for the dynamic interactions of corn production, ethanol-plant operation, and coproduct feeding to livestock. Modeling GHG emissions requires accurate biological equations derived from animal performance over a broad range of DGS feeding conditions. Summaries of DGS feeding to swine and dairy cattle were available at the time the BESS model was developed and were used in the model. A limited quantity of data on finishing cattle performance on high DGS diets was available when the model was first created. A meta-analysis was used to develop equations for feeding WDGS, whereas individual feeding studies of MDGS and DDGS were used (Liska et al., 2009; Bremer et al., 2010b). Multiple studies for all 3 DGS moistures have been completed more recently to augment initial data sets and should improve the accuracy of modeling GHG emissions from ethanol production. The objectives of this study were to update equations used in the BESS model for predicting cattle performance when fed WDGS, MDGS, and DDGS using the most complete data available and to evaluate effects of DGS moisture and inclusion level in livestock diets on GHG emissions from the cornethanol-livestock life cycle relative to gasoline.

\section{MATERIALS AND METHODS}

\section{Cattle Performance}

Several scenarios were developed using the BESS model to compare GHG reduction when ethanol is produced compared with gasoline. The scenarios were developed over a range of livestock classes and amounts of drying of coproducts. Feedlot cattle were evaluated when fed levels (10 to 40\%) of WDGS, MDGS, or DDGS. Lactating dairy cows were evaluated when fed 10 to $30 \%$ WDGS, MDGS, and DDGS. Swine were evaluated when fed only DDGS at 9 to $27 \%$ of DM.

Prior to conducting the analysis using the BESS model to estimate GHG emissions in the various scenarios, a new data set was developed to update the equations in the BESS model. Prediction equations of growth performance of feedlot cattle fed WDGS were developed from 20 feedlot cattle finishing studies with 350 pen means representing 3,365 steers (Larson et al., 1993; Ham et al., 1994; Al-Suwaiegh et al., 2002; Vander Pol et al., 2005; Godsey et al., 2008a,b; Luebbe et al., 2008; Meyer et al., 2008; Wilken et al., 2008; Corrigan et al., 2009; Rich et al., 2009; Vander Pol et al., 2009; Loza et al., 2010; Moore et al., 2010; Nuttelman et al., 2010; Rich et al., 2010; Sarturi et al., 2010). Equations for MDGS were also developed from 4 University of Nebraska-Lincoln feedlot studies with 85 pens representing 680 steers (Adams et al., 2007; Huls et al., 2008; Luebbe et al., 2008; Nuttelman et al., 2010). Equations to predict growth performance of cattle fed DDGS were developed from 4 University of Nebraska-Lincoln feedlot studies with 66 pens representing 581 steers (Ham et al., 1994; Nuttelman et al., 2010; Sarturi et al., 2010; Buckner et al., 2011). In all studies, cattle performance included DMI, ADG, and G:F, and the studies were done with highconcentrate, finishing diets.

All studies evaluated feeding corn DGS when replacing dry-rolled corn, high-moisture corn, or a blend of the two. Control diets typically contained 5 to $7.5 \%$ roughage, usually alfalfa; $5 \%$ corn-based supplement containing vitamins, trace minerals, urea if protein was limiting, monensin, and tylosin; and $87.5 \%$ corn. Individual animal carcass data were collected on all steers, and feeding performance was calculated from carcass-adjusted final BW. In each study, a single DGS moisture-type coproduct was fed as 0 to $40 \% \mathrm{DM}$ in the diet. These trials used crossbred beef steers with a mix of calf-feds and yearlings, targeting an ending point of $1.27 \mathrm{~cm}$ of back- fat. All studies were conducted under similarly managed feedlot research settings at the University of Nebraska. Animal use procedures were reviewed and approved by the University of Nebraska Institutional Animal Care and Use Committee.

To develop equations to update the BESS model, it was necessary to combine data from the experiments. Meta-analysis methodology for integrating quantitative findings from multiple studies was used for data analysis of the 3 DGS products (StPierre, 2001). This method accounts for the random effect of individual trials with a structured iterative analytical process using the PROC MIXED procedure of SAS (SAS Institute Inc., Cary, NC). Pen mean was the experimental unit. Studies were weighted by number of WDGS levels to prevent artificial linear responses from studies with zero and one other level of DGS evaluated. Each DGS moisture type was analyzed with a separate data set. Biological performance equations were developed based on significant model variables. Variables tested included DMI, ADG, and G:F. Intercepts (i.e., no DGS diet) of the MDGS and DDGS predicted performance equations were scaled to the intercept of the WDGS data set to compare differences in cattle performance relative to a common corn control diet. A common no DGS diet in the Midwest includes a combination of dry-rolled corn and high-moisture corn at 80 to $90 \%$ of the diet DM, with DGS added to the diet to replace corn. The equation adjustment allowed evaluation of how an individual steer would perform if fed 1 of the 3 products relative to a common base point.

\section{GHG Emissions}

The assumptions and calculations of BESS have been discussed extensively (Liska et al., 2009; Bremer et al., 2010b). The BESS model estimates the net energy yield from producing ethanol [i.e., ethanol plus coproduct credits (MJ) minus energy inputs $(\mathrm{MJ})]$. All outputs are then reported on a megajoules of energy basis. The 
model also estimates GHG emissions as $\mathrm{CO}_{2}$ equivalents $\left(\mathbf{C O}_{2}\right.$ eqv $)$ from nonrenewable energy sources needed to produce the corn, ethanol, and dry DGS coproducts (if needed) and transport the coproducts to animalfeeding sites. The GHG emissions are then compared with those from gasoline used as liquid fuel and reported as a percentage reduction. Energy costs (MJ) and GHG emissions with production of fossil fuels, fertilizer inputs, and electricity are included. Non-fossil-fuel GHG emissions include $\mathrm{N}_{2} \mathrm{O}$ from fertilizer and manure. Bremer et al. (2010b) further discussed the dynamic livestock and DGS components of the BESS model. Midwestern United States corn production efficiency of $362 \mathrm{~g}$ $\mathrm{CO}_{2}$ eqv $/ \mathrm{kg}$ of corn DM was used for all scenarios (Bremer et al., 2010b). Ethanol-production-facility GHG emissions from ethanol production and dryer operation were developed from a survey of 9 ethanol production facilities (Bremer et al., 2010b). Average ethanol-plant GHG emissions from natural gas and electricity use for plant operation and DGS drying were 21.0, 25.6, and $30.5 \mathrm{~g} \mathrm{CO}_{2}$ eqv/ MJ of ethanol for WDGS, MDGS, and DDGS, respectively.

We assumed that livestock production would be similar in quantity whether DGS were fed or not. Therefore, a partial budget approach was used assuming GHG emissions would be the same except for direct effects that use of DGS would have on GHG emissions, such as transportation of the DGS and livestock performance. It was further assumed that $\mathrm{CO}_{2}$ originating from corn and converted to $\mathrm{CO}_{2}$, either in the production facility or by the livestock, is resynthesized into $\mathrm{OM}$ in the subsequent growing season. McGinn et al. (2009) reported that feeding corn DDGS in foragebased growing diets reduced $\mathrm{CH}_{4}$ emissions. This was also shown by Behlke et al. (2007) in lambs. However, Behlke et al. (2007) showed higher $\mathrm{CH}_{4}$ emissions in lambs fed high grain diets when DGS was included, even though the unsaturated lipid in the DGS would be expected to reduce
$\mathrm{CH}_{4}$ emissions (Martin et al., 2008). Alternatively, digestion of the fiber in DGS compared with starch in the corn replaced would be expected to increase $\mathrm{CH}_{4}$ production (Mc Geough et al., 2010). Because of these conflicting reports and mechanisms, we chose to assume similar $\mathrm{CH}_{4}$ production by cattle fed high-concentrate diets containing DGS and those containing primarily corn. Enteric methane production losses were assumed to be $2.9 \%$ of gross energy (Bremer et al., 2010b) for finishing cattle. Gross energy was calculated with animal energy equations (NRC, 1996) that included DMI, energy content of the diet, and days on feed.

The BESS model contains equations that predict animal DMI and G:F. These equations are used to predict cattle growth to a common slaughter weight (Bremer et al., 2010b) and are largely based on NRC data. Equations for WDGS, MDGS, and DDGS were updated based on the metaanalyses described previously. Distillers grains replaced corn and urea $\mathrm{N}$ in beef finishing diets (Klopfenstein et al., 2008a) but replaced corn and soybean meal in swine finishing and dairy lactating diets (Bremer et al., 2010b). Summaries of dairy and swine DGS feeding data (Schingoethe, 2008; Stein, 2008) indicate a feeding value of DGS very similar to that of a combination of soybean meal and corn. Therefore, a direct replacement of corn and soybean meal $(\mathrm{kg} / \mathrm{kg}$ of DM) was used when DGS was fed to these animal classes.

Average emissions intensity for gasoline considering an oil sands fraction ( $7 \%$ of petroleum produced) and California reformulated gasoline blendstock is estimated at $97.7 \mathrm{~g}$ $\mathrm{CO}_{2}$ eqv/MJ. This value was used as the gasoline reference point for all scenarios (Liska and Perrin, 2009).

Corn production efficiency and ethanol-production-facility operation, except for drying of DGS, were held constant for all scenarios. The GHG emissions of ethanol production from the corn-ethanol-livestock life cycle relative to gasoline were calculated for the following scenarios. The WDGS produced at the ethanol production facility can be fed at 10,20,30, or $40 \%$ of diet DM to feedlot cattle or at 10,20 , or $30 \%$ of diet DM to lactating dairy cows. Similar scenarios for both feedlot and dairy were evaluated for MDGS and DDGS. Swine use of DGS is limited to DDGS, and scenarios of 9,18 , or $27 \%$ of finishing diet DM were evaluated.

\section{RESULTS AND DISCUSSION}

\section{Cattle Performance}

Steer DMI increased quadratically at a decreasing rate as DGS inclusion level increased (Table 1). The biggest improvement occurred when DDGS replaced corn as dry-rolled corn or high-moisture corn. The DMI response to MDGS inclusion was intermediate to DDGS and WDGS. Maximum DMI occurred at a higher level of DGS inclusion in steers fed DDGS compared with steers fed MDGS, and of the 3 DGS moisture products, the maximum DMI occurred at the lowest level of DGS inclusion in steers fed WDGS. Quadratic increases in ADG and G:F occurred when steers were fed WDGS or MDGS. Steer ADG and G:F improved linearly as DDGS replaced corn in the diet. Steer ADG was similar for the 3 DGS moisture products. All DGS products had a higher feeding value than that of corn, measured by the increase in feed efficiency of DGS diets compared with corn-based diets. Feeding values were calculated as the increase in G:F of the diet containing DGS compared with the diet with no DGS divided by the level of inclusion of DGS in the diet. The feeding values of WDGS, MDGS, and DDGS, when fed at 20 to $40 \%$ of diet DM, were 143 to $130 \%$, 124 to $117 \%$, and a constant $112 \%$ of corn (DM basis), respectively, in highconcentrate finishing cattle diets. The feeding value of DGS decreased as moisture level decreased. The feeding value of WDGS and MDGS decreased as inclusion level increased. The feeding value of DDGS was a constant $112 \%$ of corn DM. 
Table 1. Meta-analysis of finishing-steer performance when fed different dietary inclusions of corn wet distillers grains plus solubles (WDGS), modified distillers grains plus solubles (MDGS), or dried distillers grains plus solubles (DDGS) replacing dry-rolled and high-moisture corn ${ }^{1}$

\begin{tabular}{|c|c|c|c|c|c|c|c|}
\hline \multirow[b]{2}{*}{ Item } & \multicolumn{5}{|c|}{ DGS inclusion, ${ }^{2} \%$} & \multicolumn{2}{|c|}{$P$-value ${ }^{3}$} \\
\hline & 0 & 10 & 20 & 30 & 40 & Lin & Quad \\
\hline \multicolumn{8}{|l|}{ WDGS $^{4}$} \\
\hline $\mathrm{DMl}, \mathrm{kg} / \mathrm{d}$ & 10.4 & 10.6 & 10.6 & 10.4 & 10.2 & 0.01 & $<0.01$ \\
\hline$A D G, k g / d$ & 1.6 & 1.71 & 1.77 & 1.78 & 1.75 & $<0.01$ & $<0.01$ \\
\hline $\mathrm{G}: \mathrm{F}$ & 0.155 & 0.162 & 0.168 & 0.171 & 0.173 & $<0.01$ & $<0.01$ \\
\hline Feeding value, ${ }^{5} \%$ & & 150 & 143 & 136 & 130 & & \\
\hline \multicolumn{8}{|l|}{ MDGS $^{6}$} \\
\hline DMl, kg/d & 10.4 & 10.8 & 10.9 & 10.9 & 10.6 & 0.95 & $<0.01$ \\
\hline$A D G, k g / d$ & 1.6 & 1.71 & 1.77 & 1.78 & 1.74 & $<0.01$ & $<0.01$ \\
\hline $\mathrm{G}: \mathrm{F}$ & 0.155 & 0.159 & 0.162 & 0.164 & 0.165 & $<0.01$ & 0.05 \\
\hline Feeding value, $5 \%$ & & 128 & 124 & 120 & 117 & & \\
\hline \multicolumn{8}{|l|}{ DDGS $^{6}$} \\
\hline DMl, kg/d & 10.4 & 10.9 & 11.2 & 11.3 & 11.3 & $<0.01$ & 0.03 \\
\hline$A D G, k g / d$ & 1.6 & 1.66 & 1.72 & 1.77 & 1.83 & $<0.01$ & 0.5 \\
\hline $\mathrm{G}: \mathrm{F}$ & 0.155 & 0.156 & 0.158 & 0.16 & 0.162 & $<0.01$ & 0.45 \\
\hline Feeding value,,$\%$ & & 112 & 112 & 112 & 112 & & \\
\hline
\end{tabular}

${ }^{1}$ References cited in text.

${ }^{2}$ Dietary treatment levels (DM basis) of distillers grains plus solubles (DGS).

${ }^{3}$ Estimation equation linear (Lin) and quadratic (Quad) term $t$-statistic for variable-of-interest response to DGS level.

${ }^{4}$ WDGS data presented are from Bremer et al. (2010a).

${ }^{5}$ Percent of corn feeding value, calculated from DGS inclusion level feed efficiency relative to 0 WDGS feed efficiency, divided by DGS inclusion.

${ }^{6}$ MDGS and DDGS steer performance was scaled to the WDGS intercept for equal comparison across by-product types. This process was validated by Nuttelman et al. (2010).

Table 2. Percent reduction in greenhouse gas (GHG) emissions for an equivalent quantity of energy from ethanol relative to gasoline when accounting for distillers grains (DGS) moisture content, dietary inclusion level, and livestock type fed ${ }^{1}$

GHG \% reduction to gasoline ${ }^{2}$

\begin{tabular}{lccc} 
& WGS, \% of diet DM & MDGS & DDGS \\
\hline Beef & & & \\
10 & 62.4 & 53.9 & 46.1 \\
20 & 60.6 & 52.6 & 45.4 \\
30 & 58.4 & 50.9 & 44.4 \\
40 & 56.7 & 49.7 & 43.9 \\
Dairy & & & \\
10-30 & 52.6 & 47.9 & 42.8 \\
Swine & & & 42.3 \\
9-27 & - & - & \\
\hline
\end{tabular}

${ }^{1}$ WDGS = wet distillers grains with solubles; MDGS = modified wet distillers grains with solubles; and DDGS = dried distillers grains with solubles.

${ }^{2}$ Gasoline reference point is $97.7 \mathrm{~g} \mathrm{CO}_{2}$ eqv/MJ (Liska and Perrin, 2009).

\section{GHG Emissions}

All scenarios evaluated had ethanol life cycle emissions less than gasoline (Table 2). The life cycle that included feeding WDGS to feedlot cattle had the least ethanol GHG emissions of the scenarios evaluated. The next best option was feeding WDGS to dairy cows. Feeding MDGS to feedlot cattle created fewer GHG emissions than did feeding MDGS or DDGS to dairy cattle. Feeding DDGS to feedlot cattle had slightly fewer GHG emissions than feeding DDGS to swine and dairy cows.

A decrease in steer performance as moisture is removed from WDGS, as indicated by results of the metaanalyses, is in agreement with individual studies that evaluated both WDGS and DDGS (Ham et al., 1994; Nuttelman et al., 2010; Sarturi et al., 2010). Those studies evaluated 
feeding DGS in the WDGS or DDGS forms and found that the feeding value of WDGS was greater than that of DDGS. Nuttelman et al. (2010) conducted the first study to evaluate feeding multiple dietary inclusion levels of WDGS, MDGS, and DDGS in the same study. In addition, the MDGS and DDGS were sourced from the same ethanol production facility, and all 3 types of DGS were the same in nutrient composition. The researchers found the feeding value of WDGS to be greater than that of MDGS, which were both greater than that of DDGS. Results indicate cattle fed drier DGS products eat to a constant energy intake, which are supported by findings from our study that DMI of steers increased as DGS moisture decreased when compared at the same ADG.

The feeding value of DGS is set at the ethanol production facility with management decisions on how to market WDGS. Target market livestock populations and DGS transportation costs are drivers of how WDGS is processed at the ethanol production facility (Buckner et al., 2008; Bremer et al., 2010b). Drying WDGS increases storage life and decreases shipping costs. Drying DGS allows access to markets unattainable with WDGS by moving DDGS to export markets, the swine industry, and livestock industries in other regions within North America. This flexibility comes at a cost in addition to the decrease in feeding value of DDGS relative to WDGS, which is the fixed and variable cost of owning and operating a dryer in an ethanol production facility (Baumel, 2008). Ethanol-productionfacility decisions on DGS moisture management also affect the GHG balance of ethanol produced, because ethanol production facilities producing DDGS require $167 \%$ of the energy and produce $145 \%$ of the GHG emissions of ethanol production facilities producing WDGS (Liska et al., 2009). This emphasizes the need to make ethanol-production decisions that are economically and environmentally sound.
The biggest reduction of GHG emissions occurred when WDGS were fed to feedlot beef cattle close to the ethanol plant because of the greater replacement value of the coproduct for corn for beef compared with other livestock types, and because drying was not required. This is influenced by regional variability in GHG emissions from both crop and livestock production (Bremer et al., 2010b). Low inclusion levels of DGS had greater reduction of GHG emissions than did higher inclusion levels. Dairy cattle have slightly lower GHG reductions than do feedlot cattle because there is a lower replacement value of the coproducts. All livestock classes had lower reduction in overall GHG emissions when DDGS was fed because of the use of a fossil fuel to dry the coproduct.

Gasoline Reference Point. The evaluation of ethanol as a liquid fuel relative to gasoline requires accurate evaluation of the ethanol production cycle and an accurate reference point for the GHG intensity of gasoline. Gasoline emissions include combustion emissions but also upstream emissions from crude oil recovery, refinery emission, and flaring losses (Brandt and Farrell, 2007). Emissions due to military security associated with acquisition of Middle Eastern petroleum, changes in the composition of petroleum supplies toward more GHG-intensive fuels, and other additional emissions from petroleum processing must also be considered (Liska and Perrin, 2009). Indirect GHG emissions from military security for maritime oil transit are estimated to raise the GHG intensity of gasoline from the Middle East by $\sim 20 \%$ over the conventional baseline (Liska and Perrin, 2010).

Ethanol production does not displace average fossil fuel gasoline, but a marginal unit of gasoline that may have a higher environmental cost than average gasoline (US EPA, 2010). As the proportion of gasoline derived from more energy-intense processes increases, the GHG life cycle reference point of gasoline should be updated to compare a marginal liter of gasoline to an equal energy quantity from ethanol. The GHG intensity of gasoline is increasing because of depletion of efficiently accessible deposits (Brandt and Farrell, 2007). Unconventional and less efficiently processed sources of petroleum such as oil sands, coalto-liquids, and oil shale will likely be used to fill the gap between current petroleum supply and energy demand. Indeed, Canadian oil sands could supply $20 \%$ of US gasoline by 2020 (Liska and Perrin, 2009).

Indirect GHG Effects of Ethanol and Gasoline. Indirect GHG emissions from ethanol and gasoline, such as land-use change, were not evaluated in this study because of the complexity in calculating indirect GHG emissions (Liska and Perrin, 2009; US EPA, 2010). A methodology to incorporate accurate scientific knowledge about direct life cycle emissions and uncertainties concerning potentially important indirect emissions must be developed to fully evaluate the GHG mitigation potential of ethanol (Liska and Perrin, 2009; US EPA, 2010). This is especially true when indirect effects provide a large effect on the life cycle analyzed.

It is tempting to add a single indirect emission from land-use change due to increased ethanol production (Searchinger et al., 2008). However, increasing corn production to support the ethanol industry is partially offset by utilizing coproducts of the ethanol industry in livestock diets. Also, if land-use change is incorporated into the model, then all indirect emissions need to be accounted for. These include military security emissions, changes in rice cultivation, and changes in livestock production globally (Liska and Perrin, 2009; Liska and Perrin 2010; US EPA, 2010). Further research is needed before confidence in the net effects of indirect GHG emissions of both biofuels and petroleum fuels is possible (Liska and Perrin, 2009). A comprehensive assessment of GHG emissions implications of substituting ethanol for gasoline needs to be completed before effects of indirect GHG emissions from landuse change can be determined. 


\section{Current Ethanol Production Versus Future Expansion GHG}

Emissions. Indirect land-use change is associated primarily with future expansion of the ethanol production industry. Emissions from existing ethanol production facilities are limited to direct emissions, given whatever indirect emissions were associated with initiating ethanol production at these facilities has already occurred. Because of this, biofuel usage from existing facilities reduces GHG emissions from transportation fuel use compared with gasoline but also supports national security goals and rural development objectives. Evaluation of these additional policy objectives are not considered in GHG emissions modeling frameworks but are important considerations when comparing fuels.

Future Coproducts. Distillers grains are used as a CP and energy source by feedlot cattle (NRC, 1996; Klopfenstein et al., 2008a). Ruminants are able to digest the fat, fiber, and CP components of DGS. However, utilization of protein as a source of energy by animals increases $\mathrm{N}$ excretion and $\mathrm{NH}_{3}$ emissions, which are accounted for in the BESS model. Fractionation of DGS products for biodiesel production from corn oil, and potential cellulosic ethanol production of the fiber fraction, will result in a more concentrated $\mathrm{CP}$ source. The GHG balance of ethanol and other coproducts produced from fractionated corn processes may be different from the current systems analyzed because of changes in the uses of the coproducts produced, changes in corn processing, and environmental costs of implementing the technology. The feeding value of these products may also be affected (Buckner et al., 2011). Furthermore, exploitation of fibrous biomass fermentation for ethanol production would compete for the feed resource niche that cattle currently use.

Although ethanol production has altered the availability, and price, of corn for livestock production, use of DGS as livestock feed has helped maintain the synergistic relationship between the livestock and cornproduction industries. Feeding DGS results in up to $0.43 \mathrm{~kg}$ of corn DM offset as DGS for each kilogram of corn DM fermented at the ethanol production facility. The United States livestock industry is of sufficient size to fully use DGS production from the 69 billion L/yr of corn-based ethanol (Bremer et al., 2010b), or 1.7 times larger than the current 40 billion L/yr (RFA, 2009). These DGS use calculations are conservative, because they do not account for exported DGS and feeding DGS to nonlactating dairy cows, beef cattle on pasture, feedlot cattle finished in yards less than 1,000 cattle capacity, and poultry (Klopfenstein et al., 2008b).

\section{IMPLICATIONS}

Feeding DGS to livestock contributes to the environmental benefit of fuel ethanol relative to gasoline. The GHG emissions benefits of ethanol are determined by how DGS moisture is managed at the ethanol production facility and what animal classes are fed. Feeding WDGS to feedlot cattle provided the optimum feed use of DGS for livestock. Partial (MDGS) or complete drying (DDGS) of WDGS reduced the feeding value and increased ethanol GHG emissions relative to WDGS. United States state and federal GHG regulations for fuels should be continually updated and use the most representative and accurate data for assessing ethanol and gasoline GHG emissions.

\section{LITERATURE CITED}

Adams, D. R., T. J. Klopfenstein, G. E. Erickson, M. K. Luebbe, and M. A. Greenquist. 2007. The effects of sorting steers by weight into calf-fed, summer yearling and fall yearling feeding systems. J. Anim. Sci. 85(Suppl. 1):455. (Abstr.)

Al-Suwaiegh, S., K. C. Fanning, R. J. Grant, C. T. Milton, and T. J. Klopfenstein. 2002. Utilization of distillers grains from the fermentation of sorghum or corn in diets for finishing beef and lactating dairy cattle. J. Anim. Sci. 80:1105.

Baumel, C.P. 2008. Ethanol plant logistics vary: Part 1. Feedstuffs 80:16-17.
Behlke, E. J., T. G. Sanderson, T. J. Klopfenstein, and J. L. Miner. 2007. Ruminal methane production is differentially affected following replacement of dietary forage or concentrate with dried distillers grains plus solubles. J. Anim. Sci. 85(Suppl. 2):130.

Brandt, A. R., and A. E. Farrell. 2007. Scraping the bottom of the barrel: Greenhouse gas emission consequences of a transition to lowquality and synthetic petroleum resources. Clim. Change 84:241.

Bremer, V. R., K. J. Hanford, G. E. Erickson, and T. J. Klopfenstein. 2010a. Meta analysis of feeding winter calf-feds or summer yearlings wet distillers grains with different corn processing types. J. Anim. Sci. 88(Suppl. 3):127.

Bremer, V. R., A. J. Liska, T. J. Klopfenstein, G. E. Erickson, H. S. Yang, D. T. Walters, and K. G. Cassman. 2010b. Emissions savings in the corn-ethanol life cycle from feeding coproducts to livestock. J. Environ. Qual. 39:472.

Buckner, C. D., V. R. Bremer, T. J. Klopfenstein, G. E. Erickson, K. J. Vander Pol, K. K Karges, and M. L. Gibson. 2011. Evaluation of a prefermentation-fractionated by-product corn grain dry milling ethanol process in growing and finishing cattle diets. Prof. Anim. Sci. 27:295-301.

Buckner, C. D., D. R. Mark, V. R. Bremer, and G. E. Erickson. 2008. Cattle CODE: Coproduct optimizer decision evaluator. J. Ext. $46: 4$.

Corrigan, M. E., G. E. Erickson, T. J. Klopfenstein, M. K. Luebbe, K. J. Vander Pol, N. F. Meyer, C. D. Buckner, S. J. Vanness, and K. J. Hanford. 2009. Effect of corn processing method and corn wet distillers grains plus solubles inclusion level in finishing steers. J. Anim. Sci. 87:3351.

Godsey, C. M., M. K. Luebbe, G. E. Erickson, and T. J. Klopfenstein. 2008a. Effect of the grains to solubles ratio in diets containing wet distillers grains fed to feedlot steers. J. Anim. Sci. 86(Suppl. 3):62.

Godsey, C. M., M. K. Luebbe, G. E. Erickson, and T. J. Klopfenstein. 2008b. Feeding dry-rolled or steam-flaked corn with increasing levels of wet distillers grains to finishing steers. J. Anim. Sci. 86(Suppl. 2):584.

Ham, G. A., R. A. Stock, T. J. Klopfenstein, E. M. Larson, D. H. Shain, and R. P. Huffman. 1994. Wet corn distillers byproducts compared with dried corn distillers grains with solubles as a source of protein and energy for ruminant. J. Anim. Sci. 72:3246.

Huls, T. J., M. K. Luebbe, G. E. Erickson, and T. J. Klopfenstein. 2008. Effect of inclusion level of modified wet distillers grains plus solubles on feedlot performance and carcass characteristics. J. Anim. Sci. 86(Suppl. 2):118.

Klopfenstein, T. J., G. E. Erickson, and V. R. Bremer. 2008a. Board invited review: Use of 
distillers by-products in the beef cattle feeding industry. J. Anim. Sci. 86:1223.

Klopfenstein, T. J., G. E. Erickson, and V. R. Bremer. 2008b. Use of distillers co-products in diets fed to beef cattle. Pages $5-55$ in Using Distillers Grains in the U.S. and International Livestock and Poultry Industries. B. B Babcock, D. J. Hayes, and J. D. Lawrence, ed. MATRIC, Iowa State Univ., Ames. www. matric.iastate.edu/DGbook/.

Larson, E. M., R. A. Stock, T. J. Klopfenstein, M. H. Sindt, and R. P. Huffman. 1993. Feeding value of wet distillers byproducts for finishing ruminants. J. Anim. Sci. 71:2228.

Liska, A. J., and R. K. Perrin. 2009. Indirect land use emissions in the life cycle of biofuels: Regulations vs. science. Biofuels Bioproducts Biorefining. 3:318.

Liska, A. J., and R. K. Perrin. 2010. Securing foreign oil: A case for including military operations in the climate change impact of fuels. Environment 52:9.

Liska, A. J., H. S. Yang, V. R. Bremer, T. J. Klopfenstein, D. T. Walters, G. E. Erickson, and K. G. Cassman. 2009. Improvements in life cycle energy efficiency and greenhouse gas emissions of corn-ethanol. J. Ind. Ecol. $13: 58$

Loza, P. L., C. D. Buckner, K. J. Vander Pol, G. E. Erickson, T. J. Klopfenstein, and R. A. Stock. 2010. Effect of feeding combinations of wet distillers grains and wet corn gluten feed to feedlot cattle. J. Anim. Sci. 88:1061.

Luebbe, M. K., G. E. Erickson, T. J. Klopfenstein, M. A. Greenquist, and J. R. Benton. 2008. Effect of dietary cation-anion difference on feedlot performance, $\mathrm{N}$ mass balance, and manure pH. J. Anim. Sci. 86(Suppl. 3):120.

Martin, C., J. Rouel, J. P. Jouany, M. Doreau, and Y. Chilliard. 2008. Methane output and diet digestibility in response to feeding dairy cows crude linseed, extruded linseed, or linseed oil. J. Anim. Sci. 86:2642.

Mc Geough, E. J., P. O'Kiely, P. A. Foley, K. J. Hart, T. M. Boland, and D. A. Kenny. 2010. Methane emissions, feed intake, and performance of finishing beef cattle offered maize silages harvested at 4 different stages of maturity. J. Anim. Sci. 88:1479.
McGinn, S. M., Y.-H. Chung, K. A. Beauchemin, A. D. Iwaasa, and C. Grainger. 2009. Use of distillers dried grains to reduce enteric methane loss from beef cattle. Can. J. Anim. Sci. 89:409.

Meyer, N. F., G. E. Erickson, T. J. Klopfenstein, J. R. Benton, M. K. Luebbe, and S. B. Laudert. 2008. Effect of Rumensin and Tylan in feedlot diets containing wet distillers grains plus soluble to beef steers. J. Anim. Sci. 86(Suppl. 2):587.

Moore, J. P., J. T. Vasconcelos, G. E. Erickson, S. A. Furman, M. Andersen, and C. N. Macken. 2010. Effects of a dietary antioxidant on performance and carcass characteristics of feedlot cattle fed WDGS or high grain diets. J. Anim. Sci. 88(Suppl. 3):89

NRC. 1996. Nutrient Requirements of Beef Cattle. 7th ed. Natl. Acad. Press, Washington, DC.

Nuttelman, B. L., W. A. Griffin, J. R. Benton, G. E. Erickson, and T. J. Klopfenstein. 2010. Comparing dry, wet, or modified distillers grains plus solubles on feedlot cattle performance. J. Anim. Sci. 88(Suppl. 1):233

RFA (Renewable Fuels Association). 2009. Growing Innovation: Ethanol Industry Outlook 2009. RFA, Washington, DC

Rich, A. R., G. E. Erickson, T. J. Klopfenstein, M. K. Luebbe, J. R. Benton, and W. A. Griffin. 2010. Feeding increased amounts of wet distillers grains plus solubles on feedlot cattle performance. J. Anim. Sci. 88(Suppl. 3):126.

Rich, A. R., A. N. Jepson, M. K. Luebbe, G. E. Erickson, T. J. Klopfenstein, D. R. Smith, and R. A. Moxley. 2009. Vaccination to reduce the prevalence of Escherichia coli O157:H7 in feedlot cattle fed wet distillers grains plus solubles. J. Anim. Sci. 87(Suppl. 3):121.

Sarturi, J. O., J. T. Vasconcelos, G. E. Erickson, T. J. Klopfenstein, K. M. Rolfe, V. R. Bremer, M. G. Dib, and C. D. Buckner. 2010. Effects of wet corn gluten feed and wet distillers grains plus solubles on ruminal $\mathrm{pH}$, feed intake and ruminal hydrogen sulfide during grain adaptation. J. Anim. Sci. 88(Suppl. 3):69.
Schingoethe, D. 2008. Use of distillers coproducts in diets fed to dairy cattle. Pages 57-78 in Using Distillers Grains in the U.S. and International Livestock and Poultry Industries. B. B. Babcock, D. J. Hayes, and J. D. Lawrence, ed. MATRIC, Iowa State Univ. Ames. www.matric.iastate.edu/DGbook/.

Searchinger, T., R. Heimlich, R. A. Houghton, F. Dong, A. Elobeid, J. Fabiosa, S. Tokgoz, D. Hayes, and T.-H. Yu. 2008. Use of U.S. croplands for biofuels increases greenhouse gases through emissions from land-use change. Science 319:1238.

St-Pierre, N. R. 2001. Invited review: Integrating quantitative findings from multiple studies using mixed model methodology. J. Dairy Sci. 84:741.

Stein, H. H. 2008. Use of distillers co-products in diets fed to swine. Pages 79-97 in Using Distillers Grains in the U.S. and International Livestock and Poultry Industries. B. B. Babcock, D. J. Hayes, and J. D. Lawrence, ed. MATRIC, Iowa State Univ. Ames. www. matric.iastate.edu/DGbook/.

US EPA (Environmental Protection Agency). June 11, 2010. Regulation of fuels and fuel additives: Changes to renewable fuel standard program. Docket ID: EPA-HQOAR-2005-0161-0295, pg. 25040. http://www. regulations.gov/\#ldocumentDetail;D=EPAHQ-OAR-2005-0161-0295.

Vander Pol, K. J., G. E. Erickson, T. J. Klopfenstein, and M. A. Greenquist. 2005. Effect of level of wet distillers grains on feedlot performance of finishing cattle and energy value relative to corn. J. Anim. Sci. 83(Suppl. 2):55.

Vander Pol, K. J., M. K. Luebbe, G. I. Crawford, G. E. Erickson, and T. J. Klopfenstein. 2009. Performance and digestibility characteristics of finishing diets containing distillers grains, composites of corn processing coproducts, or supplemental corn oil. J. Anim. Sci. 87:639.

Wilken, M. F., M. K. Luebbe, J. R. Benton, G. E. Erickson, and T. J. Klopfenstein. 2008. Effects of feeding high levels of byproducts in different combinations to finishing cattle. J. Anim. Sci. 86(Suppl. 2):612. 